\title{
GEOARCHAEOLOGY OF THE EARLY MEDIEVAL STRONGHOLD SURROUNDINGS IN GRZYBOWO NEAR WRZEŚNIA, GREATER POLAND
}

\author{
Michą MarcinKowski ${ }^{1}$, MaŁgorzata Szczepaniak @ ${ }^{2}$ \\ ${ }^{1}$ Poznań, Poland \\ ${ }^{2}$ Institute of Geology, Adam Mickiewicz University, Poznań, Poland
}

Manuscript received: March 14, 2019

Revised version: July 30, 2019

\begin{abstract}
MarCinKowsKi M., SzczepaniaK M., 2019. Geoarchaeology of the early Medieval stronghold surroundings in Grzybowo near Września, Greater Poland. Quaestiones Geographicae 38(3), Bogucki Wydawnictwo Naukowe, Poznań, pp. 95-108. 8 figs, 4 tables.

ABSTRACT: The stronghold in Grzybowo (Rabieżyce village) near Września is a remnant of medieval ring-fort. It is investigated to a considerably lower degree than similar objects from Greater Poland. The analysis of archival data shows that the stronghold is located on the edge of the flood plain of the Struga River formed by Holocene sediments, cutting into the moraine plateau. Analysis of sediments in the stronghold vicinity revealed interlayers of organic matter and sandy deposits rich in calcium carbonate with variable grain size composition, particularly west of the stronghold (i.e. in the valley floor). Moreover, radiocarbon data set showed a considerably older than Holocene age of the sediment. The analysis of the course of the contemporary river channel also allowed for stating hypotheses regarding a potentially different course of the former Struga River channel and its changes during the development of the stronghold. These assumptions were based on the analysis of the archaeological archival data, where field drawings suggest the existence of such a channel in the territory of the stronghold.
\end{abstract}

KEY wORDs: lithology, anthropogenic changes, stronghold, Middle Ages, Grzybowo

Corresponding author: Małgorzata Szczepaniak, malgorzata.szczepaniak@amu.edu.pl

\section{Introduction}

During the human occupation of the area, it has been constantly transformed and adjusted to human needs. Human impact on the natural environment can be direct or indirect (Latocha, Traczyk 2006). The direct effect is more evident in the landscape. The basic components of the abiotic environment are new landforms developed by man, such as the stronghold in Grzybowo (Fig. 1). In the case of the biotic environmental components, the record is more difficult to determine, and hence its analysis is more challenging, as exemplified by results of pollen analysis.

The modern landscape in the vicinity of the stronghold particularly results from natural processes predominant in the development of land relief. Anthropogenic morphogenetic activity is observed in the undertaken groundworks that revealed relicts of the stronghold's rampart and moat, still visible today. Throughout centuries since its abandonment, the stronghold has been 
subjecting of gradual degradation. The natural functioning and course of the Struga River are most likely also influenced by human activity (Petri, Bakiewicz 2002).

Like many times in the past, also in the Middle Ages climatic changes were very dynamic (Fig. 2 ), and fluvial systems were very sensitive to environmental changes. In the Early Middle Ages (a time interval important for this study), the "small climatic optimum" is described by Lamb (1984) as a warm period. Büntgen et al. (2011) reconstructed climate variability in the European territory in the Early Middle Ages (Fig. 2).

Due to well-developed channels, rivers in Poland rarely flooded in the warm dry sub-period $\left(6^{\text {th }}-10 / 11^{\text {th }}\right.$ century $\left.A D\right)$. According to Maruszczak (1998), this could have favoured settlement along river channels. In the $7^{\text {th }}-8^{\text {th }}$ century $\mathrm{AD}$, however, the climate was relatively cold and dry (Dobrowolski et al. 2018). The warm humid sub-period $\left(9^{\text {th }}-13 / 14^{\text {th }}\right.$ century) was a period most favourable to human existence.
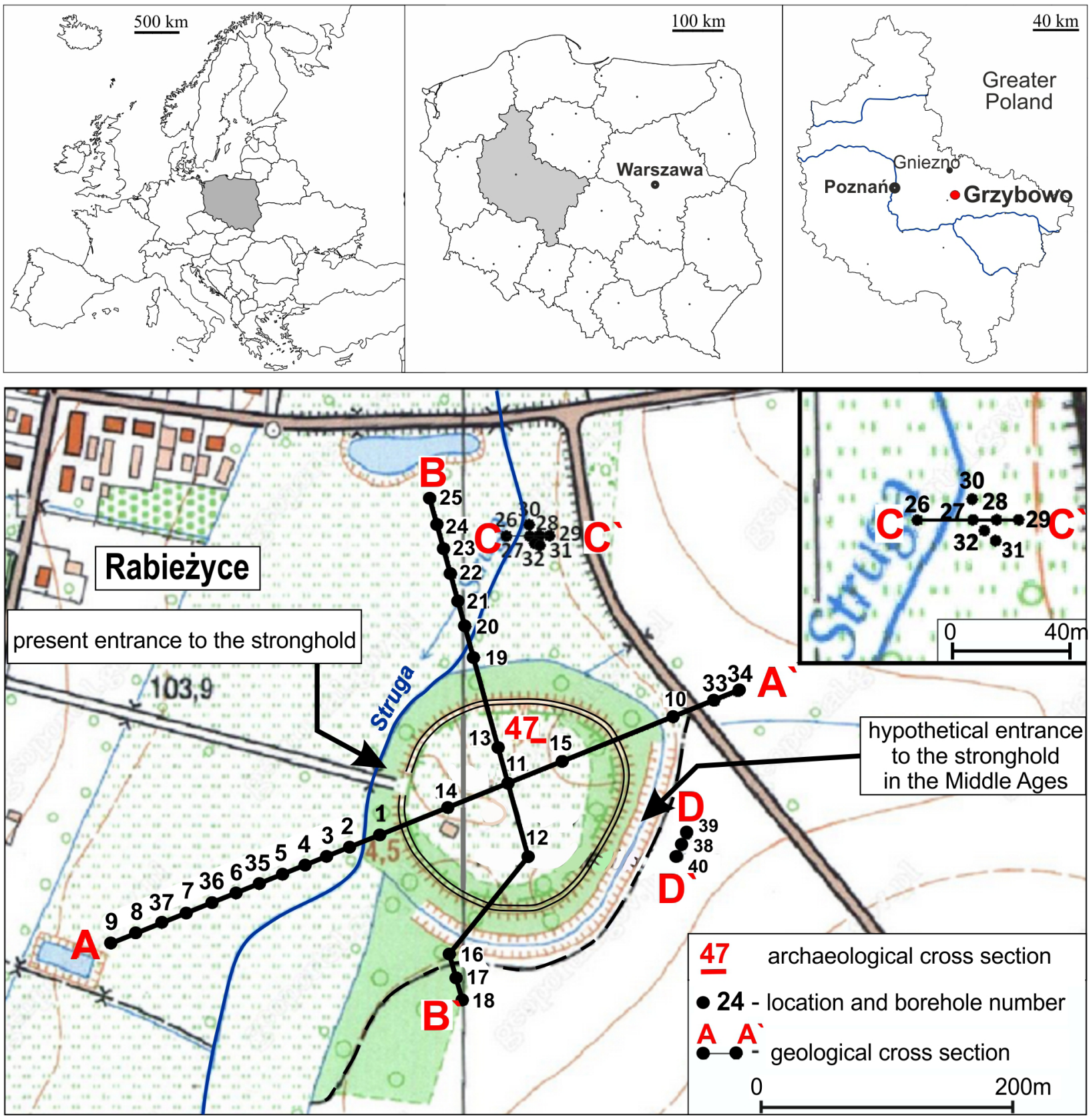

Fig. 1. Location of the study area with marked location of boreholes, cross-section lines of the stronghold area, and archaeological excavation (profile 47). 




Fig. 2. Amount of precipitation and temperature anomalies in the Middle Ages after Büntgen et al. (2011) - simplified.

Intensive landscape transformations and adaptations to the settlement were common at the time. Rivers also carried much more water than in the previous centuries (Maruszczak 1998). Higher than average humidity caused greater floods already in the mid $11^{\text {th }}$ century (Kalis et al. 2003, Michczyńska et al. 2013, Semkowicz 1922, Starkel et al. 2006, 2013, 2015).

According to the latest archaeological research, the stronghold in Grzybowo was abandoned in the mid $11^{\text {th }}$ century (there are no archaeological finds younger than $11^{\text {th }}$-century). Notice that climatic fluctuations could have had a direct effect not only on the abandonment of the stronghold, but also on the characteristics of sediments around it. There is no clear evidence, however, that the stronghold was abandoned for natural or political reasons.

The possibility of a change in the course of the Struga River channel during the functioning of the Grzybowo ring fort has also become an aim of the study. From its source in the vicinity of Gniezno to the river mouth to the Bawól River near Krępkowo, the river very gently meanders through a quite narrow valley to Gutów Wielki. Below the municipality, the meanders of Struga are more and more prominent. Only a short fragment of the channel near the stronghold in Grzybowo is almost straight, and preceded by a sharp bend, also appearing right behind the stronghold (Fig. 1). Considering the aforementioned meandering character of Struga River, resulting from the dynamics of waters in a flat area of among others Greater Poland, its straight section next to the stronghold raises questions. In addition to other methods, archaeological data was also analysed.

The interior of the stronghold is investigated considerably more thoroughly, because archaeological works have been conducted there for more than 20 years. Five boreholes were performed in its area (Fig. 1), aimed at preserving the continuous character of the profiles (to introduce them to the archaeological contour map), and the determination of the thickness of the cultural layers, their composition, and their depth of deposition.

The main aim of the study is the reconstruction of the geomorphological, geological and hydrological situation related to the location of the stronghold in Grzybowo-Rabieżyce. The research was based on selected sedimentological and chemical methods and radiocarbon dating. Based on the lithology and stratigraphy of sediments in the vicinity of the stronghold, a reconstruction of the medieval environment of the ring fort vicinity was attempted. An attempt was also undertaken to confirm the hypothesis on the originally different course of the Struga River channel (boreholes Nos. 26 to 32 were planned in a way to capture the potential old channel). This hypothesis appeared during the field work and after suggestions made by archaeologists based on the non-natural (perhaps anthropogenic) shape of the Struga River channel (Petri, Bakiewicz 2002, Tuszyński 2002). The minor objective of the study was an attempt to determine the course of the road that could have led to the stronghold from the eastern side in the Early Middle Ages.

\section{Geology and geomorphology of the stronghold area}

The region belongs to the Września Plain Mesoregion, covering the southern part of the Wielkopolska Lakeland. The plain is extended in the southern and western range of the Poznan Phase of the Weichselian glaciation delineated by the Gniezno Lakeland. To the west it neighbours 
to the Poznan Gap of the Warta River, to the south to the Śrem Basin and the Konin Valley (Kondracki 2002).

Pleistocene fluvioglacial sands and gravels of the outwash plain surround the stronghold from the east, and clays occurring outside the Struga River channel (especially from the west) (Sydow, Machowiak 2000, 2003). Clays and deluvial sands north of the stronghold are an effect of slope processes. Westside of the stronghold, Holocene sandy alluvium occurs within the valley floor (Sydow, Machowiak 2000).

The study area is inclined to the SE, in the direction of the Warta River valley. Altitudes vary from 103 to $120 \mathrm{~m}$ a.s.l. The highest places are related to moraine hills (NW from the stronghold), and the lowest heights occur in the Struga River valley (Fig. 3).

The relief of the area was primarily determined by the geomorphological processes during the Weichselian Glaciation, and especially in the Leszno Phase, Poznań Phase, and Gniezno Oscillation. Transformations in the Late Weichselian and in the Holocene influenced the region morphology in smaller degree (Sydow, Machowiak 2003).

The area is formed mostly by a moraine plateau with low kame elevations, almost devoid of lakes. The end moraine hills of the Poznań phase were dated to 18,400 BP (Kozarski 1986).

The stronghold is located within the subglacial channel developed during the deglaciation of the Weichselian ice sheet of the PoznanPomeranian phase (Sydow, Machowiak 2003). According to Krygowski $(1953,1961)$, the area is a narrow outwash plain developed within the subglacial channel dissecting the moraine plateau. Also Karczewski et al. (2007) described this area as an outwash plain (Fig. 3). The land relief can be described as post-glacial with predominant

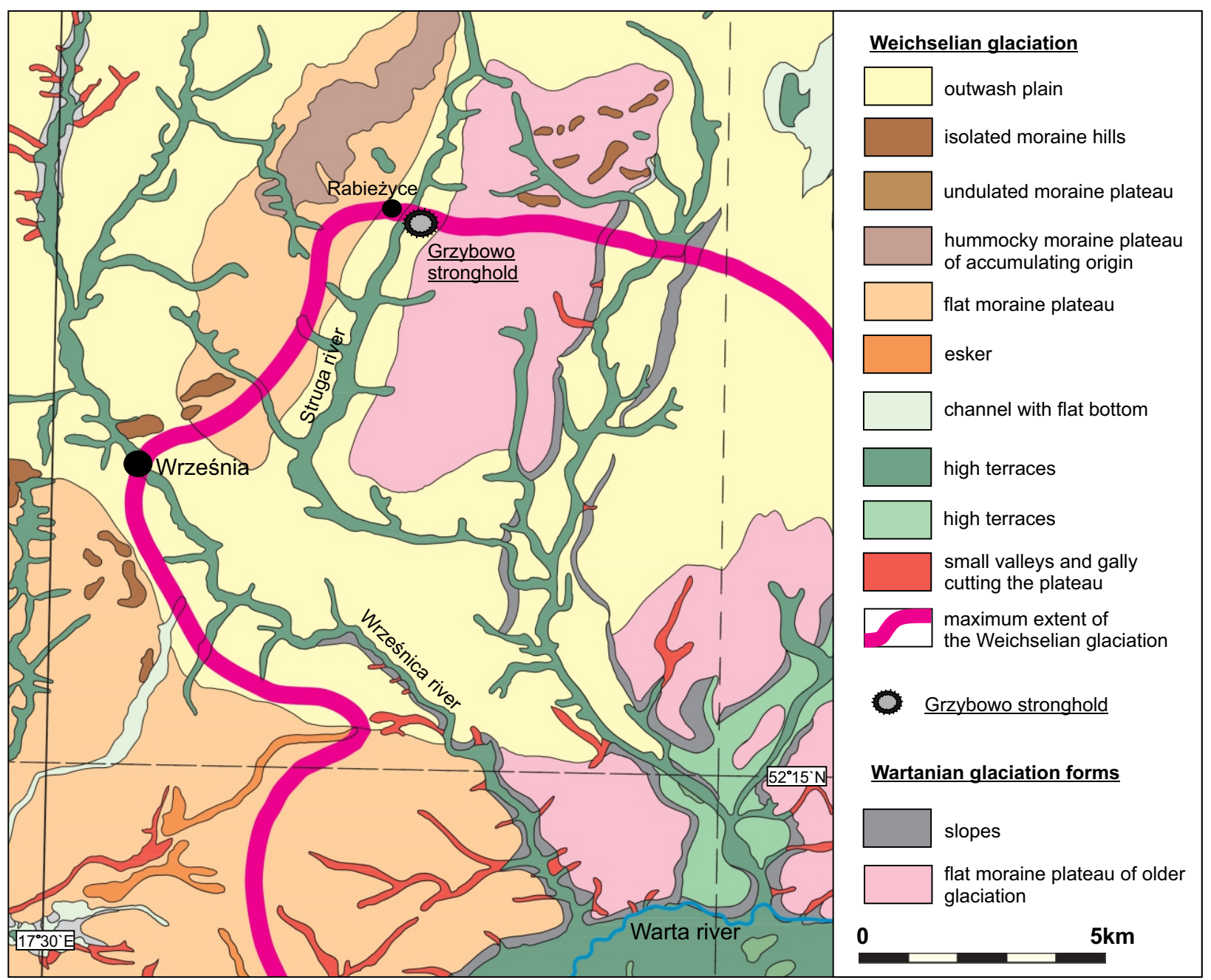

Fig. 3. Fragment of the geomorphological map of Greater Poland after Karczewski et al. (2007), changed. 
landforms of glacial and glacifluvial origin. The valley of the meandering Struga River has a length of about $30 \mathrm{~km}$.

\section{Archaeological background}

The study of the stronghold in Grzybowo (located on the border of the Rabieżyce village, approximately $6 \mathrm{~km}$ NE of Września, in the Greater Poland Voivodeship) commenced in 1988. Earlier, before the Second World War, only occasional field work had been conducted (Brzeski 1938). The research was carried out particularly in the field archaeological works.

The time of functioning of the ring fort in Grzybowo was very short as for construction of that kind. It is dated from the $10^{\text {th }}$ to the beginning of the $11^{\text {th }}$ century of the Early Piast period (Kurnatowska 2011). The total area of the stronghold is approximately $4.7 \mathrm{ha}$, and its inner area reaches 2.2 ha. The best state of preservation of the rampart relicts is observed in the NE part of the stronghold (Fig. 4), where they reach $9 \mathrm{~m}$ in height. Their height in the period of functioning of the ring fort could have reached even $16 \mathrm{~m}$
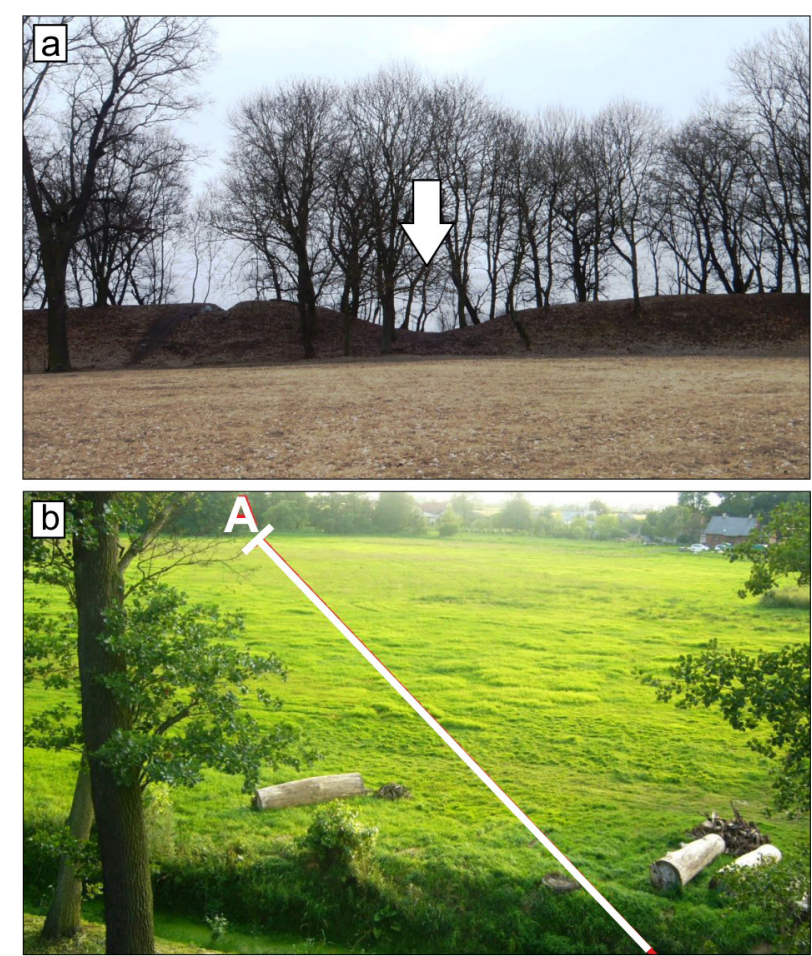

Fig. 4. View of the stronghold.

a) lowering in the embankments, b) view to the west of the stronghold with marked cross-section line A-A exceeding the boundary of the embankments.
(Petri 1998). The construction of ramparts such as those in Grzybowo followed a typical way of building fortifications by the first Piasts (made of specially arranged wood), as in Gniezno, Giecz, or Kalisz (Brzeski et al. 2000, Kurnatowska, Tuszyński 1996, Tuszyński 1995).

The stronghold in Grzybowo is typologically ring-shaped (Kowalenko 1938). This type of strongholds was constructed in flat and open areas, permitting free management of the occupied land, including the height and course of the rampart, and width and depth of the moat. The considerable extent of the Grzybowo ring fort area and height of the rampart in comparison to objects from Giecz and Ostrów Lednicki, or small ones from Bródka or Rokutów, may prove its high importance in the Piast state (Kowalenko 1938).

Access to the ring fort was probably restricted on the east side by the moat. On the south side, north side, and the west side, the stronghold is surrounded by wetlands (Fig. 4 b). In the eastern part of the embankment, a lowering is visible (Fig. 4 a). It is sometimes interpreted by archaeologists as a potential trace of the original gate leading to the ring fort. The stronghold also had another gate in the northern part, a so-called side gate. Such a solution is also encountered in other Slavic strongholds. The currently used entrance to the area of the stronghold to the west has been built in the modern times, similarly as the ditch surrounding the entire object (Kurnatowska, Tuszyński 2003).

\section{Material and Methods}

Until 1988, the research on Grzybowo stronghold was primarily focused on the archaeological aspect and was later gradually supplemented by interdisciplinary studies. In order to implement the aforementioned aims, four geological cross-sections were made based on 40 boreholes. Archival cartographic materials and archaeological documentation from subsequent stages of the excavations in the stronghold were verified. For the purpose of implementation of the planned geological cross-sections, the boreholes were performed every $20 \mathrm{~m}$ on average, with variable depths. The maximum core depth was $3.9 \mathrm{~m}$. The boreholes involved the collection of a total of 220 
lithological samples. 169 samples were subject to sedimentological analysis, including sieve analysis, aerometric analysis, determination of the content of calcium carbonate in the sediments, organic matter content analysis, and radiocarbon dating of selected samples of organic deposits.

Sedimentological analysis were performed at the laboratory of the Geological Institute of the Adam Mickiewicz University in Poznan. All the analysis were performed pursuant to the guidelines for particular analysis (Kostrzewski 1988, Myślińska 2006, Wiłun 1976). In the case of the sieve analysis, each sediment sample was devoid of grains larger than $40 \mathrm{~mm}$, and had a constant weight of 200-250 g. The analysis employed a column of sieves with the following dimensions of square mesh: $2.0,1.6,1.0,0.8,0.5,0.25,0.125$, and $0.063 \mathrm{~mm}$. A total of 114 sediment samples were analysed by means of the sieve method (the results were analysed by means of the Siewca software). The aerometric analysis was applied for a total of 30 sediment samples. The analysis concerned particles with supplementary diameters of less than $0.063 / 0.071 \mathrm{~mm}$ in the case of cohesive soils (Wiłun 1976, Myślińska 2006). The analysis were performed for samples of sediment with a diameter of less than $1 \mathrm{~mm}$ and a weight of $40 \mathrm{~g}$ with the application of $20 \mathrm{ml}$ colgen $\left(\mathrm{Na}_{2} \mathrm{CO}_{3}\right)+\left(\mathrm{Na}_{6} \mathrm{P}_{6} \mathrm{O}_{12}\right)$ and redistilled water. The obtained results of the sieve and aerometric analysis were fed into the "Siewca" software, where based on the obtained grain size curves and histograms, corresponding names of sediments were ascribed.

The determination of ash content (content of the organic substance in a sample in [\%] - i.e. loss on ignition) was performed according to the methodology described by Myślińska (2006) for 13 samples with macroscopic features suggesting a substantial content of organic matter. The content of $\mathrm{CaCO}_{3}$ in sediment samples was determined by means of the "calcite bomb" method, constituting a simplified Scheibler's method providing comparable results in a shorter time after Woszczyk and Szczepaniak (2008).

Radiocarbon datings were made in the Poznan Radiocarbon Laboratory using the acceleration mass spectrometer (AMS) technique. The method was applied in the analysis of two samples. Samples for dating were collected in two ways. A small amount of sediment was sampled from the middle part of the layer with a determined high content of organic matter. In the other case, fragments of non-decomposed wood were collected from a sediment sample. The interpretation of results considered among others the "old wood" problem and the reservoir effect (Geyh, Schleicher 1990, Schiffer 1986, Walanus, Goslar 2009).

Based on the results of laboratory lithological analysis, four geological cross-sections with different lengths were designated. The longest one A-A' -500 m (Fig. 1, 5 a) with SW-NE orientation, as well as cross-section B-B' (Fig. 5 b) with NW-SE orientation, particularly aimed at the determination of the lithology and relative stratigraphy of sediments outside as well as within the stronghold. This permitted the determination of the correlation of lithology with the morphology of the stronghold area. The short cross-section C-C' (Fig. 5 c) north of the stronghold, with a W-E orientation, provided a vertical section of the small part of the Struga River valley floor below its bend. The last of the cross-sections D-D' (Fig. 5 d) with approximately N-S orientation aimed at capturing the alleged road that potentially led to the stronghold from the east in the Early Middle Ages. Single boreholes also covered sites within the turn of the Struga River in front of the stronghold. They were aimed to point to references to the hypothesis on a different course of the Struga River in the past, and potential human influence on its course. The age of sediments was based on relative archaeological chronology (lack of absolute datings), as well as geomorphological assumptions and results of radiocarbon ${ }^{14} \mathrm{C}$ datings for two samples. Due to difficulties in the performance of boreholes in cross-section D-D', the profile was shifted to the distance of 20 $\mathrm{m}$ from the moat. The stones were encountered at a low depth (approximately $20-40 \mathrm{~cm}$ ). Due to this, further drilling in that place was not possible. No permission was granted to perform an excavation in the area of an arable field.

Materials undergoing analysis also included archive archaeological data of the excavation expedition in Grzybowo from the years 1989-2004 (Archive data of the excavations in Grzybowo in 1989-2004, Petri 1998, Tuszyński 2002). The crucial for presented geological results is archival archaeological documentation of excavation No. 47 (Petri, Bakiewicz 2002) (marked in Fig. 1, 7). Its cross-section probably shows an outline of a 

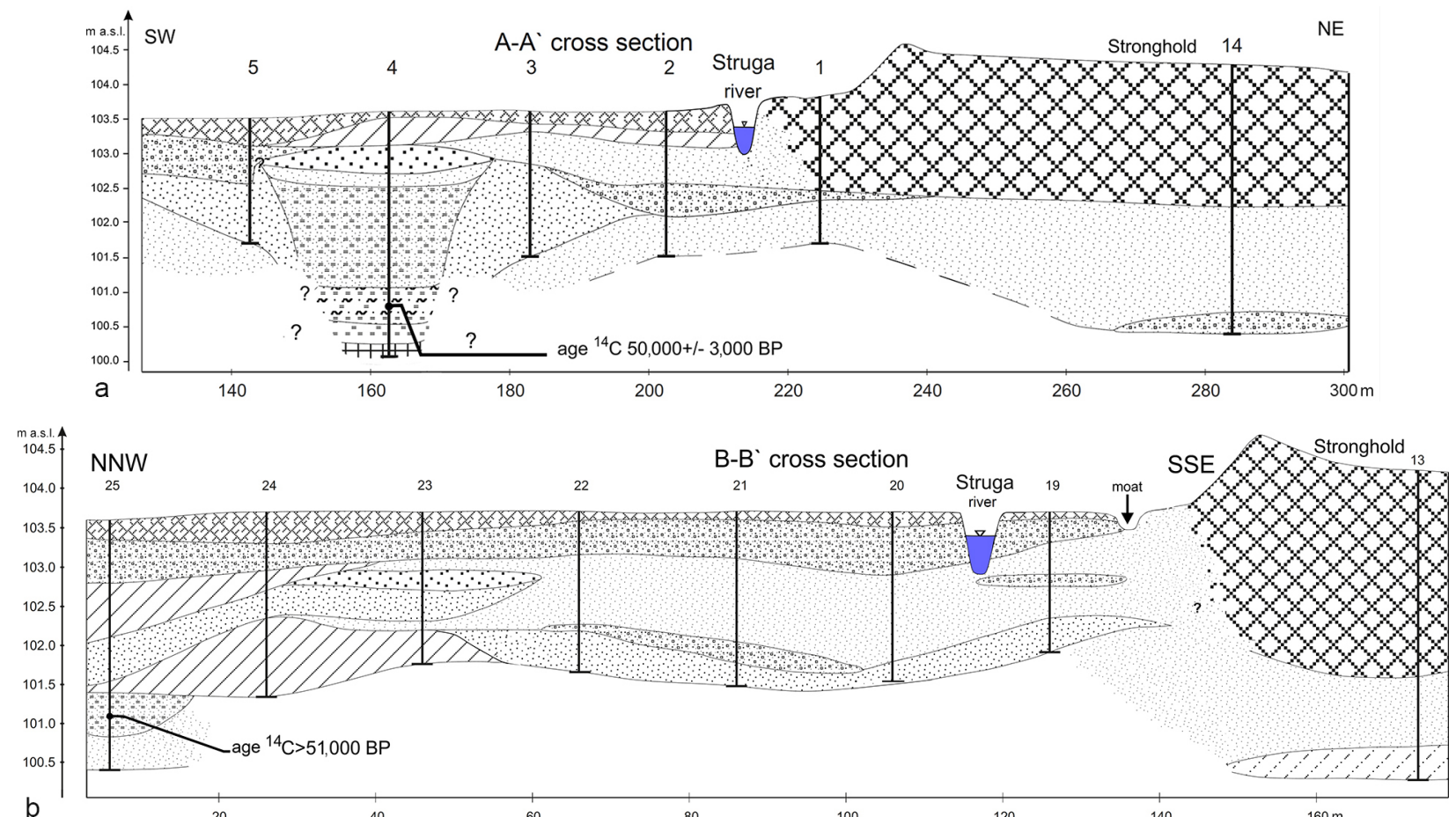

b

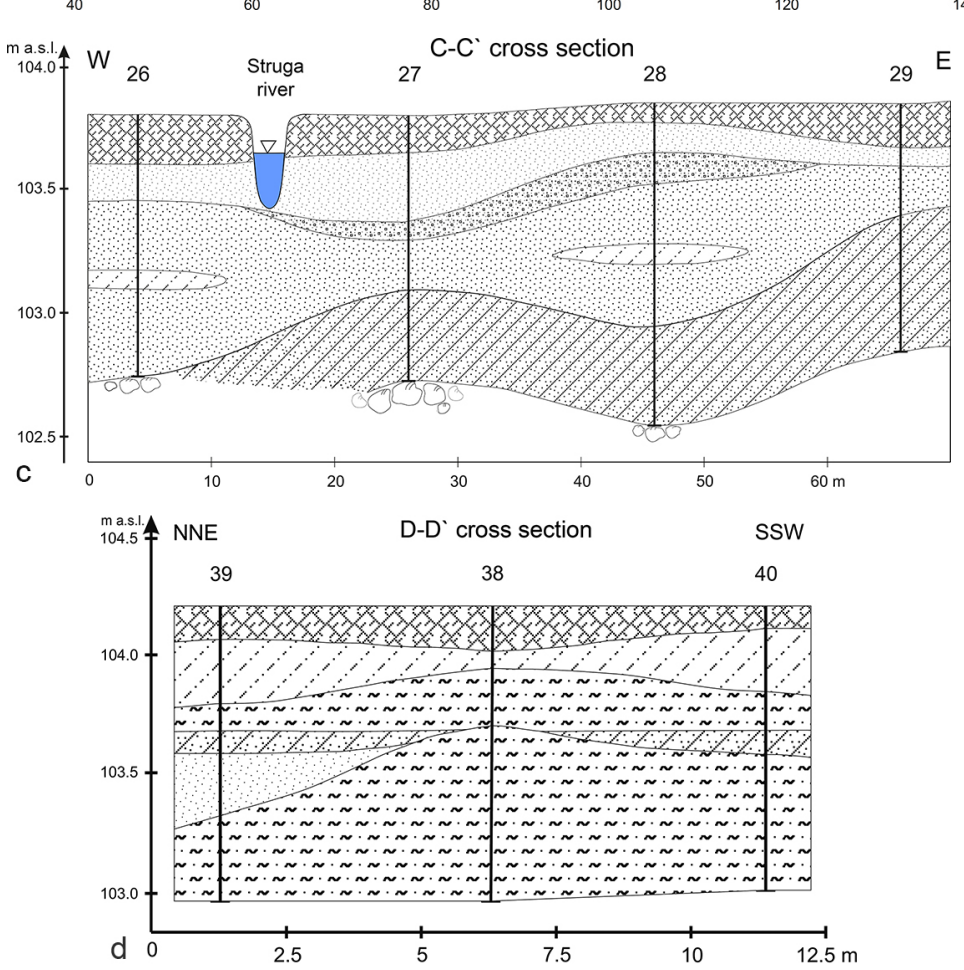

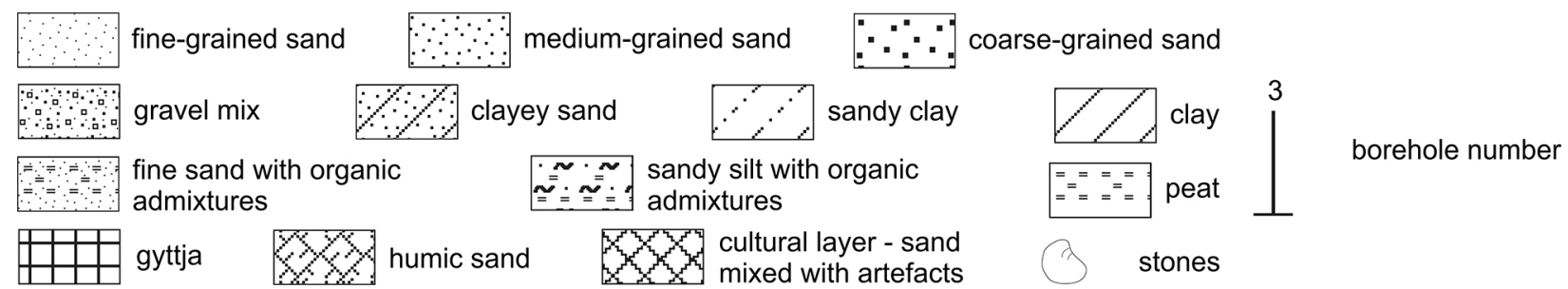

Fig. 5. Geological cross sections around the stronghold.

a) fragment of the profile $A-A^{\prime}, b$ ) fragment of the profile $\left.B-B^{`}, c\right)$ profile $C_{-} C^{\prime}$, d) profile $D^{-} D^{\prime}$. 
buried river channel: the cross-section through the channel of a meandering river (banks with different inclinations in accordance with the cross-section of a typical meandering river) with a visible internal and external bank of the river. The cross-section corresponds with the morphology of the river in its bend (the accumulation and erosion slope, however the size is surprisingly small) (Fig. 7). However, lithology is very simplified. The alluvial deposits of the meandering river and any sedimentary structures are not marked on the figure of Petri and Bakiewicz (2002) (Fig. 7).

\section{Interpretation of results and discussion}

The macroscopic and laboratory analysis of the obtained Quaternary deposits permitted their qualification to three groups:

- limnoglacial sediments represented by dammed lake clays, silty clays, and sandy clays;

- swamp and lacustrine organic deposits peats, gyttjas, and organic muds;

- fluvial sediments - various-grained sands and gravels.

During the sieve and aerometric analysis of 144 samples, ten different types of sediments were separated (Table 1).

In the Struga River palaeochannel, limnic and/or peatland deposits were encountered only in one out of 11 boreholes of profile A-A'. Borehole No. 4 revealed organic deposits in the form of peat. The remaining boreholes within profile $A-A^{\prime}$ (Westside of the stronghold) showed similar and simple lithology (Fig. 5 a). Fine sands and sandy gravels are predominant in these boreholes. In borehole No. 4 , the former channel of the Struga River was most probably recorded, separated from the main stream of the river as a palaeomeander. However, it can be discussed that so old river channel of meandering river cut almost from the present-day surface. It could be interpreted as a layer of organic deposits and sandy silts with organic admixtures covered with fluvial or glacifluvial sands. The entire sequence of organic sediments in borehole No. 4 begins at a depth of $110 \mathrm{~cm}$ below ground level. Its bottom was not reached by the core, ending at a depth of $350 \mathrm{~cm}$ below ground level. The top layer is composed of fine-grained sand with an
Table 1. Results of the sieve and aerometric analysis for 144 samples from boreholes Nos. 1 to 40 .

\begin{tabular}{|r|l|c|}
\hline & \multicolumn{1}{|c|}{ Sediments } & Number of the samples \\
\hline 1 & Fine-grained sand & 62 samples \\
\hline 2 & Medium-grained sand & 25 samples \\
\hline 3 & Coarse-grained sand & 2 samples \\
\hline 4 & Clayey sand & 5 samples \\
\hline 5 & Sandy clay & 14 samples \\
\hline 6 & Compact clay & 5 samples \\
\hline 7 & Clay & 3 samples \\
\hline 8 & Sandy silt & 3 samples \\
\hline 9 & Gravel mix & 14 samples \\
\hline 10 & Clayey gravel & 11 samples \\
\hline
\end{tabular}

organic substance. It was deposited on sandy silt, also with organic matter admixtures. Peat occurring at a depth of 300-330 cm was not strongly compact, with a moderate degree of decomposition. A sharp boundary between peat and the overlying sediment suggests relatively fast drying and therefore overgrowing of the separated presumed palaeomeander by other sediments. The result of the LOI analysis proved the highest among all the analysed deposits in the profile (Table 2). The peat was deposited on a layer of sediment described as gyttja, recorded in the core reaching a depth of $350 \mathrm{~cm}$.

The result of radiocarbon dating of peat from borehole No. 4 from a depth of 300-310 cm is interesting. In accordance with earlier archaeological suggestions (Kurnatowska 2011) that the depression around the stronghold could be filled with Holocene sediments, the date of the end of the last glaciation was expected. The result $(50,000 \pm 3,000$ years BP - out of range, Table 4) did not confirm the preliminary presumptions. The obtained age shows that the early presumed channel of the Struga River should be older than assumed. The river might have also brought older allochthonous organic matter. The analysed sediments in borehole No. 4 above $130 \mathrm{~m}$ a.s.l. are covered with clay, which also suggests age older than Weichselian glaciation (Fig. 5 a). Notice, however, that the diversity of sediments in the studied borehole can be interpreted differently, not only as a river channel. This is mainly due to gyttja and peat at the bottom of the profile. They are sediments typical of the lacustrine environment, potentially covered with fluvial or glacifluvial sands.

Prevalence of fine- and medium-grained sand and sandy gravel is observed in almost all boreholes in profile B-B' (Fig. 5 b). Borehole 25 seems 
Table 2. Loss on ignition analysis of different samples with visible organic matter.

\begin{tabular}{|c|c|c|l|}
\hline Borehole No. & Depth [cm] & Ignition loss [\%] & \multicolumn{1}{|c|}{ Sediment } \\
\hline 1 & $40-60$ & 7.91 & Fine-grained sand \\
\hline 4 & $120-150$ & 4.95 & Sandy clay \\
\hline 4 & $245-260$ & 11.04 & Fine-grained sand \\
\hline 4 & $293-300$ & 19.11 & Sandy silt \\
\hline 4 & $300-310$ & 47.27 & Peat \\
\hline 4 & $330-350$ & 21.35 & Gyttja \\
\hline 8 & $150-180$ & 1.64 & Clayey sand \\
\hline 10 & $50-70$ & 3.50 & Clay \\
\hline 12 & $20-40$ & 2.91 & Fine-grained sand \\
\hline 19 & $25-40$ & 9.69 & Gravel mix \\
\hline 19 & $130-150$ & 10.85 & Medium-grained sand \\
\hline 25 & $205-220$ & 2.56 & Clay \\
\hline 25 & $220-260$ & 31.09 & Find-grained sand with organic \\
\hline
\end{tabular}

to be the most interesting. At a depth of $220 \mathrm{~cm}$ below ground level, a layer of fine-grained sand with organic matter occurred, with a thickness of $55 \mathrm{~cm}$ (Fig. $5 \mathrm{~b}$ ). It was among layers showing the highest diversity of sediments. Content of organic matter in the layer was high (Table 2). Loss on Ignition in the deposits reached $47 \%$. Organic matter from a depth of $220-260 \mathrm{~cm}$ was also a subject to radiocarbon dating. The age for the sample exceeded the possibilities of dating (Table 4, Fig. 6).

This can suggest that the subglacial channel used by the Struga River developed more than 50 thousand years ago, presumably during the Świecie stadial or earlier, and not in the Poznań-Pomeranian phase, as stated by Sydow and Machowiak (2003). According to Sydow and Machowiak (2000), the Holocene alluvium of valley floor occurs west of the stronghold. The modern access road leading to the stronghold runs through it.

The potential existence of a water reservoir (shallow lake) west of the stronghold (Fig. 5 a) was also assumed by many earlier archaeological papers (Brzeski 1938, Brzeski et al. 2000, Kurnatowska, Tuszyński 2003), although it was not confirmed by geological research. One of the oldest known maps for the area with visible landscape and morphology elements was a Reymann's Special Map No. 96 and German Geological Map from 1894 (Lepsius 1894). Older encountered cartographic materials present the area in an excessively generalised way, and do not permit a detailed comparative analysis of the contemporary and modern environment. Both maps from the $19^{\text {th }}$ and $20^{\text {th }}$ century, however, present a wetland zone extended along the Struga River channel which has not changed its course since that time. The boreholes revealed sandy sediments, sandy sediments with organic matter, and coarser fractions that may contradict the hypothesis on the long-term functioning of a water body in the area. However, they do not exclude their periodical (seasonal) occurrence. That is why the authors assume that this area was most probably only periodically flooded. The precise age of the sediments is unknown. Due to the lack of excavation or observation of sedimentation structures, it is difficult to ascribe the sediments to particular facies.

Lack of detailed information on the shallow geological structure of the vicinity of the stronghold continues to constitute a problem in the context of attempts of reconstruction of the history

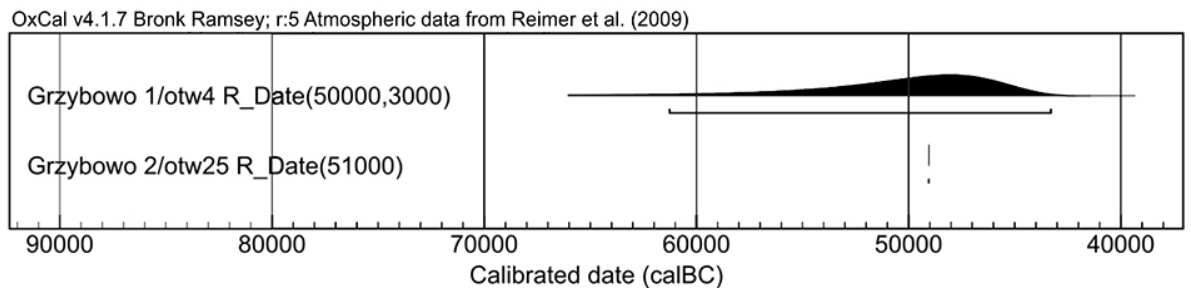

Fig. 6. Calibration of radiocarbon data set in graphical form. 
of the stronghold. The thickness of cultural layers in the stronghold is variable and depends on the place of occurrence - the highest thickness in in the NW part of the stronghold, where the socalled small stronghold existed. While the lowest thickness is in the SE part of the stronghold. These layer is fine-grained sand, rarely medium-grained sand mixed with artefacts and small irregular humus layers. The deepest bottom of the cultural layer was found in borehole No. 13 at a depth of $280 \mathrm{~cm}$ below ground level. In the deepest borehole No. 14, at a depth from 360 to $390 \mathrm{~cm}$, sandy gravel occurs. It is covered by a thick layer of fine sand. At a depth of approximately $102 \mathrm{~m}$. a.s.l. and above, fine sand turns into fine sand with admixtures characteristic of cultural layers (small pieces of wood, organic, thicker fraction, fragments of bones). The same situation was observed in boreholes No. 11, 12, and 15. It therefore seems that the natural substrate on which the stronghold was founded was a very thick layer of fine sand. Material at smaller depths is considerably mixed and anthropogenically transformed.

The pattern and character of layers in profile D-D' (Fig. 1, 5 d) showed no evident disturbance that could be caused by anthropogenic activity. Although the layers are almost symmetrical towards the presumed road axis, it is difficult to be certain of its unnatural origin. No cobblestones or any other material the road (the existence of which was assumed by archaeologists) could be paved with was found up to a depth of $2 \mathrm{~m}$ below ground level.

The analysis of plant macroremains in the analysed samples showed no content of vegetative and generative remains of aquatic plants.
Table 3. Content of $\mathrm{CaCO}_{3}$ in particular samples.

\begin{tabular}{|c|c|c|c|}
\hline $\begin{array}{c}\text { Borehole } \\
\text { No. }\end{array}$ & $\begin{array}{c}\text { Depth of the } \\
\text { sample }[\mathrm{cm}]\end{array}$ & $\begin{array}{c}\text { Content of } \\
\mathrm{CaCO}_{3}[\%]\end{array}$ & Sediments \\
\hline 4 & $330-350$ & 22 & Gyttja \\
\hline 24 & $75-100$ & 14 & Clay \\
\hline 29 & $50-85$ & 14 & Clayey sand \\
\hline 31 & $110-130$ & 6 & Clayey sand \\
\hline 33 & $50-70$ & 10 & Sandy clay \\
\hline 34 & $35-55$ & 9 & Sandy clay \\
\hline 38 & $55-70$ & 11 & Sandy silt \\
\hline 39 & $85-100$ & 9 & Sandy silt \\
\hline 39 & $185-200$ & $<5$ & Sandy silt \\
\hline 40 & $75-100$ & 9 & Sandy silt \\
\hline
\end{tabular}

Lithology and stratigraphy point to glacial accumulation (Fig. 5). Clays with an admixture of calcium carbonate occur in the form of continuous layers, and not single points. The mean content of $\mathrm{CaCO}_{3}$ in the layer was $10 \%$ (Table 3).

Possibility of a change in the course of the Struga River channel during the functioning of the Grzybowo ring fort was also considered. The anthropogenic genesis of the straight course of the river near the stronghold was presumed here. It was associated with the location and further stages of construction of the early medieval stronghold which would force such a course of the river channel. Based on the performed boreholes, supplemented by archaeological documentation (Petri, Bakiewicz 2002; Fig. 7), a reconstruction of the original course of the river channel in the area in the Middle Ages was attempted (Fig. 1, 5). Results of drillings in the zone are surprising. Coring was discontinued in the boreholes due to the presence of a high amount of very thick material (presumably gravels) in the ground, deposited at a similar depth of $215-225 \mathrm{~cm}$, making the performance of deeper manual drillings

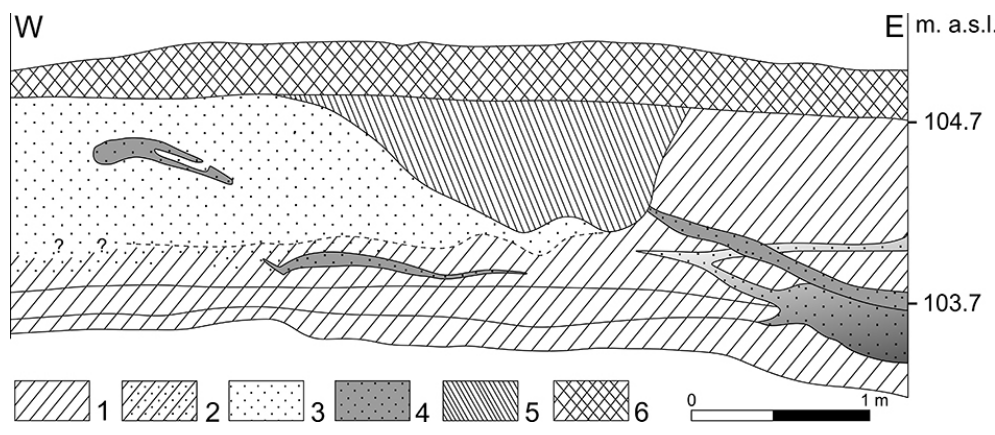

Fig. 7. Profile of archaeological section 47 according to Petri and Bakiewicz (2002, simplified), with a visible outline of a river bed filled with dark-brown sediments.

1 - clay with humic admixtures, 2 - sandy clay, 3 - sand with artefacts, 4 - sand with humus, 5 - dark brown sand, 6 - humic sand (described by archaeologist as an arable layer). 
impossible. No convincing evidence was recorded in any of the planned drillings.

The archaeological profile (Fig. 7) presented in Petri and Bakiewicz (2002) still suggests, however, that the river channel could have changed its position during the functioning of the ring fort. The cross-section on Fig. 7 shows the outline of the probable meandering river channel filled with dark brown deposits.

Lithology within the discussed profile is as follows: on the bottom clayey sand is deposited, underlying a layer of medium-coarse sand with a high amount of iron compounds. This sand horizon also contains interlayers of $\mathrm{CaCO}_{3}$ reaching $14 \%$ (Table 3). In the upper part, a layer of sandy gravel is deposited.

The lithology of borehole No. 14 in profile A- $\mathrm{A}^{\prime}$ is characteristic. It is located on the line of the course of the presumed former channel of Struga within the stronghold (Fig. 1, 5). It supports the hypothesis concerning a change in the course of the Struga River channel (however, not in the same time as the presumed channel in the stronghold - in this borehole the bottom of cultural layer is at depth of. ca. $102 \mathrm{~m}$ a.s.l., the bottom of the presumed channel (Fig. 7) in the stronghold is at ca. $104 \mathrm{~m}$ a.s.l). It is horizon $360 \mathrm{~cm}$ below ground level, where the fraction of sandy-gravel sediments, presumably fluvioglacial, begins. The final, and the most evident argument is provided by the archival archaeological documentation of excavation No. 47 (Fig. 1, 7). It supports the earlier presumptions. According to calculations, the excavation is located on the line of the alleged former channel, and cuts through it perpendicularly (Archive data of the excavation expedition in Grzybowo in 1989-2004, Petri 1998, Petri, Bakiewicz 2002, Tuszyński 2002). Its cross-section shows an outline of a presumed buried river channel. The depth of the probable channel is very shallow. Unfortunately, it is not possible to reconstruct the actual dimensions of the channel, because the stronghold was used as an arable field for a long time, and deep ploughing contributed to the devastation of the uppermost parts of the objects. The figure suggests, however, that in this place, the Struga channel had a width of at least $2.2 \mathrm{~m}$, and its minimum depth was $0.75 \mathrm{~m}$ (Fig. 7), or perhaps deeper. These are values possible to determine by archaeological research.

The hypothesis of a change in the course of the river channel corresponds with the known history of the stronghold in Grzybowo. A much smaller older-phase ring fort originally existed there, with a diameter of approximately $80 \mathrm{~m}$, located in the NW corner of the later ring fort (Kurnatowska, Tuszyński 2003, Petri 2006; Fig. $8 \mathrm{a}, \mathrm{b})$. Struga River could have surrounded the stronghold to the east, and not to the west as it is the case today. This interpretation is based on results of archaeological research (including an archaeological cross-section made inside of the stronghold, Petri, Bakiewicz 2002, Tuszyński 2002; Fig. 7), and current geological analysis.

According to archaeological data, the transformation of the natural environment commenced at the beginning of the $10^{\text {th }}$ century AD (918/922930/935 AD) with the decision on the construction of a stronghold in the area (Kurnatowska 2011). The small stronghold was located on the right bank of the river, securing it to the east with a water barrier (Fig. 8 a, b). The western side was protected by wetlands.

In the mid $10^{\text {th }}$ century $\mathrm{AD}$ (940 AD), the stronghold was expanded to the larger size. It was planned to expand towards the east (Petri 1998, Kurnatowska 2011), probably despite the presence of the river channel. The problem was overcome, most probably first through digging

Table 4. Calibration of radiocarbon data set; made with OxCal v4.2.4 (Bronk Ramsey 2013) and IntCal13 atmospheric curve (Reimer et al. 2013).

\begin{tabular}{|c|c|c|c|c|c|c|}
\hline $\begin{array}{c}\text { Sample no./ } \\
\text { borehole no./ } \\
\text { depth }\end{array}$ & Lab. code & Lab. comments & Material & ${ }^{14} \mathrm{C}$ age $\mathrm{BP}$ & $\begin{array}{c}\text { Age after } \\
\text { calibration } \\
68 \%[\mathrm{BC}]\end{array}$ & $\begin{array}{l}\text { Age after } \\
\text { calibration } \\
95 \%[\mathrm{BC}]\end{array}$ \\
\hline $\begin{array}{l}\text { Grzybowo 1/ } \\
\text { otw4/ } \\
310 \mathrm{~cm}\end{array}$ & Poz-56565 & $\begin{array}{c}\text { Date out of range - } \\
50,000 \pm 3,000 \mathrm{BP}\end{array}$ & wood & $\begin{array}{c}50,000 \pm 3,000 \\
\mathrm{BP}\end{array}$ & $\begin{array}{c}52,769 \text { BC } \\
(68.2 \%) 45,099 \\
\text { BC }\end{array}$ & $\begin{array}{c}61,269 \text { BC } \\
(95.4 \%) 43,298 \\
\text { BC }\end{array}$ \\
\hline $\begin{array}{l}\text { Grzybowo 2/ } \\
\text { otw25/ } \\
220-260 \mathrm{~cm}\end{array}$ & Poz-56607 & $\begin{array}{c}\text { Date out of range - } \\
51,000 \mathrm{BP}\end{array}$ & $\begin{array}{l}\text { organic frag- } \\
\text { ments from sand }\end{array}$ & $>51,000 \mathrm{BP}$ & $\begin{array}{c}49,052 \mathrm{BC} \\
(68.2 \%) 49,051 \\
\text { BC }\end{array}$ & $\begin{array}{c}49,052 \mathrm{BC} \\
(95.4 \%) 49,051 \\
\text { BC }\end{array}$ \\
\hline
\end{tabular}


an artificial canal or ditch running on the outer side of the new ramparts, west of the embankments. Water flow was directed into the dug canal (Fig. 8 c, d). Embankments of a new larger ring fort were also built, forming a large moat around the stronghold. The old river channel was then buried.

\section{Conclusion}

The main goal of the current study was to determine the lithology and relative stratigraphy of sediments in the vicinity of the stronghold. That was achieved by implementing laboratory analysis and designation of geological cross-sections. The verification of the assumed hypothesis on a different course of the Struga River channel in the past was also attempted.
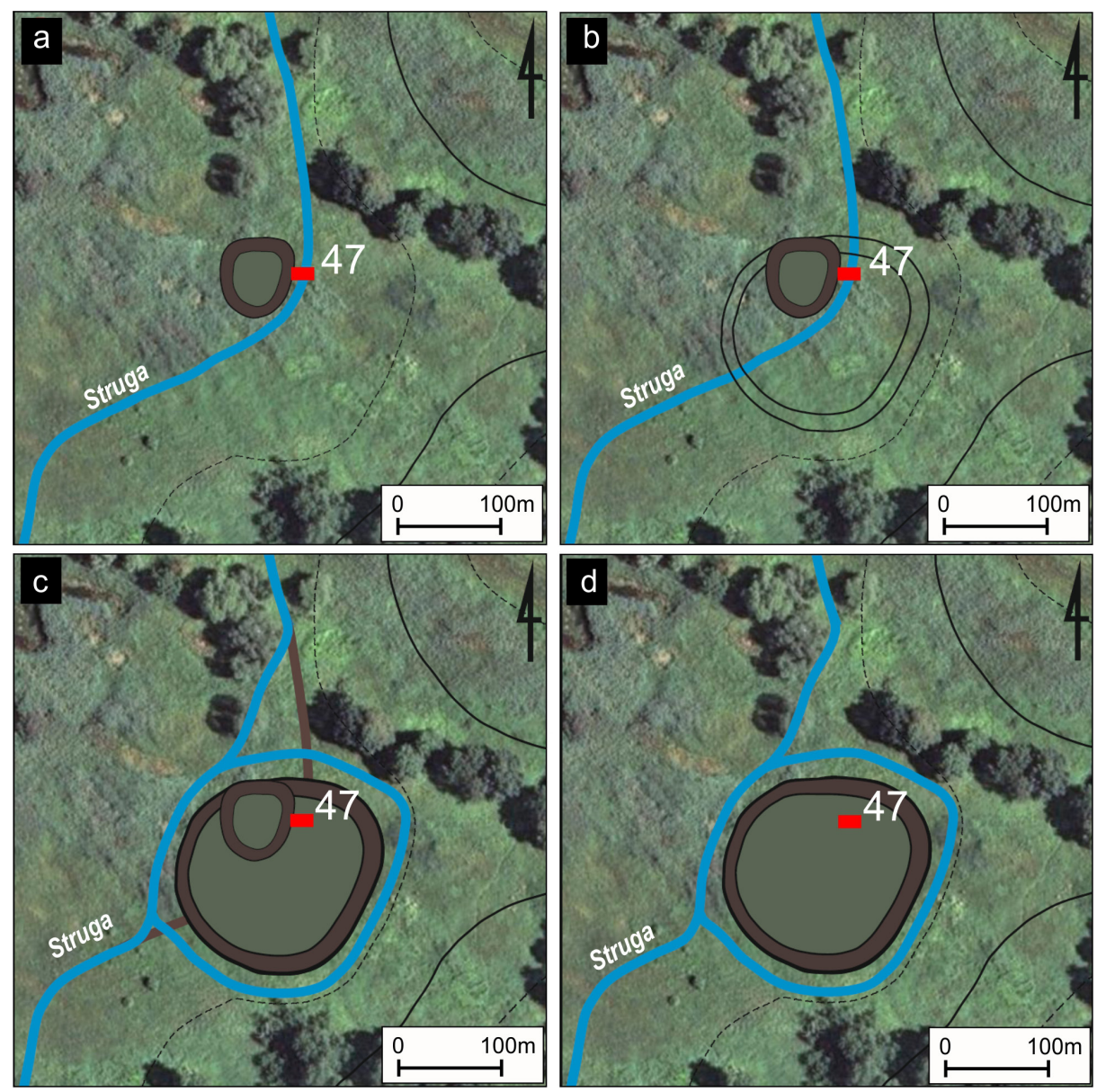

Fig. 8. Proposal of the reconstruction of subsequent stages of the change in the location of the Struga River channel based on geological research, stages of development of the stronghold according to archaeological research results (Petri 2006, Petri, Bakiewicz 2002).

a) and b) the older phase of the ring fort, c) younger phase with visible marked older phase, d) the younger phase of the ring fort; archaeological excavation no. 47 marked by a red colour. 
The aspect of abandonment of the stronghold after a relatively short time from its expansion remains enigmatic. Only its abandonment for natural causes can be excluded here, i.e. an increase in the water level in the surrounding lake which according to the research did not exist.

\section{Acknowledgements}

The field work and radiocarbon dating were funded by the Institute of Geology, Adam Mickiewicz University. We would like to thank Mr. Jacek Wrzesiński from the Archaeological Reserve in Grzybowo stronghold (Museum of the First Piasts at Lednica) for all the help in the field work and valuable remarks in the field.

\section{Author's contribution}

The authors divide the contribution percentage as follows: Michał Marcinkowski - 60\%, Małgorzata Szczepaniak $40 \%$.

\section{References}

Archive data of the excavation expedition in Grzybowo in 19892004 from Krystyna Sulkowska-Tuszyńska and Jacek Wrzesiński. MS.

Brzeski O., 1938. Grodzisko wczesnohistoryczne w Grzybowie w pow. wrzesińskim. Z Otchtani Wieków 13 11-12: 151-153.

Brzeski O., Kurnatowska Z., Tuszyński M., 2000. Dziesięciolecie badań wykopaliskowych grodziska w Grzybowie gm. Września woj. Wielkopolskie. Wielkopolskie Sprawozdania Archeologiczne, Poznań 5: 57-72.

Büntgen U., Tegel W., Nicolussi K., McCormick M., Frank D., Trouet V., Kaplan J.O., Herzig F., Heussner K.U., Wanner H., Luterbacher J., Esper J., 2011. 2500 Years of European Climate Variability and Human Susceptibility. Science 331 6017: 578-582. DOI: 10.1126/ science.1197175.

Dobrowolski R., Rodzik J., Mroczek P., Zagórski P., Bałaga K., Wołoszyn M., Dzieńkowski T., Hajdas I., Fedorowicz S., 2018. Environmental conditions of settlement in the vicinity of the mediaeval capital of the Cherven Towns (Czermno site, Hrubieszów Basin, Eastern Poland). Quaternary International 493(10): 258-273. DOI:10.1016/j. quaint.2018.05.042.

Geyh M.A., Schleicher H., 1990. Absolute Age Determination. Physical and Chemical Dating Methods and Their Application. Springer - Verlag, Berlin, Heidelberg.

Kalis A.J., Merkt J., Wunderlich J., 2003. Environmental changes during the Holocene climatic optimum in central Europe - human impact and natural causes. Quaternary Science Reviews 22: 33-79. DOI: 10.1016/S02773791(02)00181-6.

Karczewski A., Mazurek M., Stach A., Zwoliński Z., 2007. Mapa geomorfologiczna Niziny Wielkopolsko-Kujawskiej pod redakcja B. Krygowskiego w skali 1: 300 000. Opracowanie numeryczne. Instytut Paleogeografii i Geoekologii, Uniwersytet im. A. Mickiewicza, Poznań.

Kondracki J., 2002. Geografia regionalna Polski. Wydawnictwo Naukowe PWN, Warszawa.

Kostrzewski W., 1988. Parametry geotechniczne gruntów budowlanych oraz metody ich oznaczania. Wydawnictwo Politechniki Poznańskiej, Poznań.

Kowalenko W., 1938. Grody i osadnictwo grodowe Wielkopolski wczesnohistoryczne (od VII do XII wieku). Nakładem Polskiego Towarzystwa Prehistorycznego, Poznań: 49-60.

Kozarski S., 1986. Skale czasu a rytm zdarzeń geomorfologicznych Vistulianu na Niżu Polskim. Czasopismo Geograficzne 57(2): 248-270.

Krygowski B., 1953. Mapa geomorfologiczna Niziny Wielkopolsko-Kujawskiej.

Krygowski B., 1961. Geografia fizyczna Niziny Wielkopolskiej, cz. I Geomorfologia. PTPN, Poznań.

Kurnatowska Z., 2011. Grzybowo pod Wrześnią - potężny gród wczesnopiastowski. Landform Analysis 16: 56-58.

Kurnatowska Z., Tuszyński M., 1996. Wczesnośredniowieczne grodzisko w Grzybowie pod Wrześnią. Kronika Wielkopolski, Poznań 4 (79): 76-85.

Kurnatowska Z., Tuszyński M., 2003. Gród Wczesnopiastowski w Grzybowie pod Wrześnią. In: M. Brzostowicz, Z. Hilczer-Kurnatowska (eds.), Archeologia Powiatu Wrzesińskiego. Poznań-Września: 163-185.

Lamb H.H., 1984. Climate in the Last Thousand Years: Natural Climatic Fluctuations and Change. In: H. Flohn, R. Fantechi (eds.), The Climate of Europe: Past, Present and Future. D. Reidel, Dordrecht, The Netherlands: 25-64.

Latocha A., Traczyk A. (eds.), 2006. Zapis działalności człowieka w środowisku przyrodniczym. Metody badań i studia przypadków. Wyd. Gajt, Wrocław.

Lepsius R., 1894. Geologische Karte Des Deutschen Reichs in 27 Blättern. Sect. 16: Posen.

Maruszczak H., 1998. Naturalne tendencje zmian krajobrazu Polski środkowej w ciągu ostatnich piętnastu stuleci. In: K. Turkowska (ed.), Przemiany krajobrazu naturalnego Polski. Łódź: ŁTN, Acta Geographica Lodziensia 74: 149-160.

Michczyńska D., Starkel L., Nalepka D., Pazdur A., 2013. Hydrological Changes after the last ice retreat in Northern Poland using radiocarbon dating. Radiocarbon 55 (2-3): 1712-1723. DOI: 10.1017/S0033822200048633.

Myślińska E., 2006. Laboratoryjne badania gruntów. Wydawnictwa Uniwersytetu Warszawskiego, Warszawa.

Petri B., 1998. Überlegungen, Abschätzungen und Berechnungen zur frühmittelalterlichen slawischen Ringwällen von Burganlagen. MS.

Petri I., Bakiewicz A., 2002. Ekspedycja Wykopaliskowa Komisji Archeologicznej PTPN i Fundacji Brzeskich w Grzybowie. Polowy Dziennik Naukowy Badań (Field scientific research documentation), Wykop 47. MS.

Reimer P.J., Bard E., Bayliss A., Beck J.W., Blackwell P.G., Bronk Ramsey C., Grootes P.M., Guilderson T.P., Haflidason H., Hajdas I., Hattz C., Heaton T.J., Hoffmann D.L., Hogg A.G., Hughen K.A., Kaiser K.F., Kromer B., Manning S.W., Niu M., Reimer R.W., Richards D.A., Scott E.M., Southon J.R., Staff R.A., Turney C.S.M., van der Plicht J., 2013. IntCal13 and Marine13 radiocarbon age calibration curves 0-50,000 Years cal BP. Radiocarbon 55: 1869-1887. DOI: 10.2458/azu_js_rc.55.16947.

Reymann's Topographische Special Karte Von Central Europa (1806-1908), Special-Karte No. 96 sheet: Peisern, in scale 1:200 000 
Semkowicz W., 1922. Zagadnienie klimatu w czasach historycznych. Przeglad Geograficzny 3: 18-42.

Schiffer M.B., 1986. Radiocarbon dating and the "old wood" problem: the case of the Hohokam chronology. Journal of Archaeological Science 13(1): 13-30. DOI: 10.1016/03054403(86)90024-5.

Starkel L., Soja R., Michczyńska D.J., 2006. Past hydrological events reflected in Holocene history of Polish rivers. $\mathrm{Ca}$ tena 66: 24-33. DOI: 10.1016/j.catena.2005.07.008.

Starkel L., Michczyńska D., Krąpiec M., Margielewski W., Nalepka D., Pazdur A., 2013. Progress in the Holocene chrono-climatostratigraphy of Polish territory. Geochronometria 40(1): 1-21. DOI: 10.2478/s13386-012-0024-2.

Starkel L., Michczyńska D.J., Gębica P., Kiss T., Panin A., Persoui J., 2015. Climatic fluctuations reflected in the evolution of fluvial systems of Central-Eastern Europe (60-8 ka cal BP). Quaternary International 388: 97-118. DOI: 10.1016/j.quaint.2015.04.017.

Sydow S., Machowiak W., 2000. Szczegótowa mapa geologiczna Polski w skali1:50 000, Arkusz Psary Polskie. Wydawnictwa Geologiczne, Warszawa.
Sydow S., Machowiak W., 2003. Objaśniania do Szczegótowej mapy geologicznej Polski w skali 1: 50 000. Ministerstwo Środowiska i Państwowy Instytut Geologiczny, Warszawa.

Tuszyński M., 1995. Grodzisko w Grzybowie, stan. 1, gm. Września, woj. Poznańskie. Doniesienie wstępne. Wielkopolskie Sprawozdania Archeologiczne, Poznań 3: 201-204.

Tuszyński M., 2002. Dziennik Naukowy Badań, Grzybowo gm. Września, stan. 1 - Grodzisko, Wykop 47. MS.

Walanus A., Goslar T., 2009. Datowanie radioweglowe. Wydawnictwa AGH, Kraków.

Wiłun Z., 1976. Zarys Geotechniki. Wydawnictwa Komunikacji i Łączności, Warszawa.

Woszczyk M., Szczepaniak M., 2008. Reevaluation of the Scheibler method and its usefulness in the analysis of carbonate content in lake sediments. In: E. Bajkiewicz-Grabowska, D. Borowiak (eds.), Anthropogenic and natural transformations of lakes. vol. 2, Wyd. KLUGPTLimn, Gdańsk: 223-225. 